\title{
Quality Management in the Customer Service Process
}

\author{
Roma MARCZEWSKA-KUŹMA ${ }^{1}$, Arkadiusz KOWALSKI ${ }^{2}$, Václav ZUBR ${ }^{3}$ \\ ${ }^{1}$ Poznan University of Technology, Poznań, Poland \\ roma.marczewska-kuzma@put.poznan.pl \\ ${ }^{2}$ Wroclaw University of Science and Technology, Wrocław, Poland \\ arkadiusz. kowalski@pwr.edu.pl \\ ${ }^{3}$ University of Hradec Králové, Hradec Králové, Czech Republic \\ vaclav.zubr@uhk.cz
}

\begin{abstract}
The article pays particular attention to the importance of appropriate customer segmentation in the quality management of the customer service process. Detailed analysis of the changes of customer's expectations can be conducted on the basis of assumptions of customer's life cycle, understood as the stages of customer's purchasing activity. Several concepts related to this issue have been introduced in the literature of the subject: Customer Relationship Life Cycle (CRLC), Customer's Activity Cycle (CLAN), The Relationship Life Cycle (RLC). Studies were carried out in three stages: Stage 1: interviews on company's activities, employees, customers, customer service process. Stage 2: analysis and evaluation of internal documentation of enterprises, including customer service contracts, procedures, and instructions for customer service. Stage 3: confronting the opinions of respondents (I and II) with their customers' opinions on the quality of services provided by the company and the risks identified in the course of the customer service process. The research section provides a proposal of customer segmentation prepared on the basis of a case study of three manufacturing companies from the construction industry and three groups of packages of actions that can be undertaken within the framework of customer target groups were prepared.
\end{abstract}

Keywords: Quality Management, Customer Service Process, Customer Segmentation, Customer Life Cycle.

\section{Introduction}

Customer service can be treated as a process, i.e. as "a specific category of organization's resources that ensure synchronization of other resources used in the aspect of changes" [6]. The ISO 9000:2015 standard defines this term as: "the organization's relationship with the customer during the life cycle of a product or service" [17]. This process is required to be sustainable while maintaining adaptability in the areas of inter alia market, legal and other requirements.

Due to changing and growing needs of our customers, the intensity of competitive struggle is also increasing. In the economic literature, is there many approaches to 
the term "competitiveness". The competitiveness studies can be conducted at different levels enterprises [3]. Competent staff in the customer's mind is one of the key factors in purchasing a product or service. Properly trained staff can help you achieve your competitive advantage. Therefore, every company should make employees aware of the essence of a positive approach to the customer [12]. This dynamic of change requires quick and accurate decision making by the company. Faster and easier decision making is facilitated by customer segmentation understood as a method of "analyzing the complex reality of customers' needs, perceptions and expectations by classifying clients into a limited number of homogeneous groups - i.e. groups of people with similar needs, perceptions or expectations" [9].

It should be noted that the perception modifies the initial assessment of the product/service performed by the customer. Factors influencing perception include company image, psychological filters such as memory, knowledge, beliefs, values and physical filters, which reduce/modify the level of quality and reliability of the product/service, i.e. touch, sight, etc. Perception can also be considered in terms of the ability to perceive, interpret and use information available in the environment for decision making. The system of perception consists of the senses and their ability to perceive the stimuli or to distinguish changes in their level (differences) and the process of interpretation and psychological "processing" of information [22].

Detailed analysis of the changes of customer's expectations can be conducted on the basis of assumptions of customer's life cycle, understood as the stages of customer's purchasing activity, which is dependent, among others, on from the time of cooperation with the company and characterized by varied customer behavior and customer service costs [14]. The terms used in the definition of relationship marketing suggest that there are stages in the relationship with the client. Several concepts related to this issue have been introduced in the literature of the subject. The bestknown ones are [24]:

- Customer relationship life cycle (CRLC),

- Customer's activity cycle, according to K. Rogoziński (CLAN),

- The relationship life cycle (RLC) of Tzokas N. and Saren M.

The Table 1 presents the description of these three approaches to the staged approach to customer cooperation. The cyclicality of customer's relations with the company has been presented in the literature in four phases with the same description, for each of the three proposals for the name of this phenomenon.

A set of measurable and intangible characteristics determining the extent to which the customer's needs are satisfied $[5,10]$. Customer value for the company is defined as "the value of these streams, which are generated by customers throughout the whole period of the client-company relationship. The higher the value of these streams for the company, the higher the customer value is, and this translates into a higher value of the company and value for other stakeholders" [2].

It is very difficult for an enterprise to determine the value offered to a customer, as it requires analysis of the rationality of customer behavior. The concept of rationality is defined on the basis of many fields. The term most relevant to the problematic issue of the article is derived from economics and mean "behavior aimed at maximizing 
usability, i.e. maximizing effects while minimizing costs and efforts incurred in order to achieve the assumed objectives" [22].

Analyzing the offered value for the customer against the actual expected value gives companies the opportunity to plan and apply pre-emptive actions, understood as planning goals in a strategic perspective. Unlike the satisfaction test, it allows both corrective and preventive action to be taken. According to the concept of dynamical minimalism, one should strive towards the essence of processes [8]. Preventive action is possible due to the use of e. g. benchmarking and value assessment for potential customers.

Table 1. Cyclicality of client-business relations in the literature [4, 19, 23].

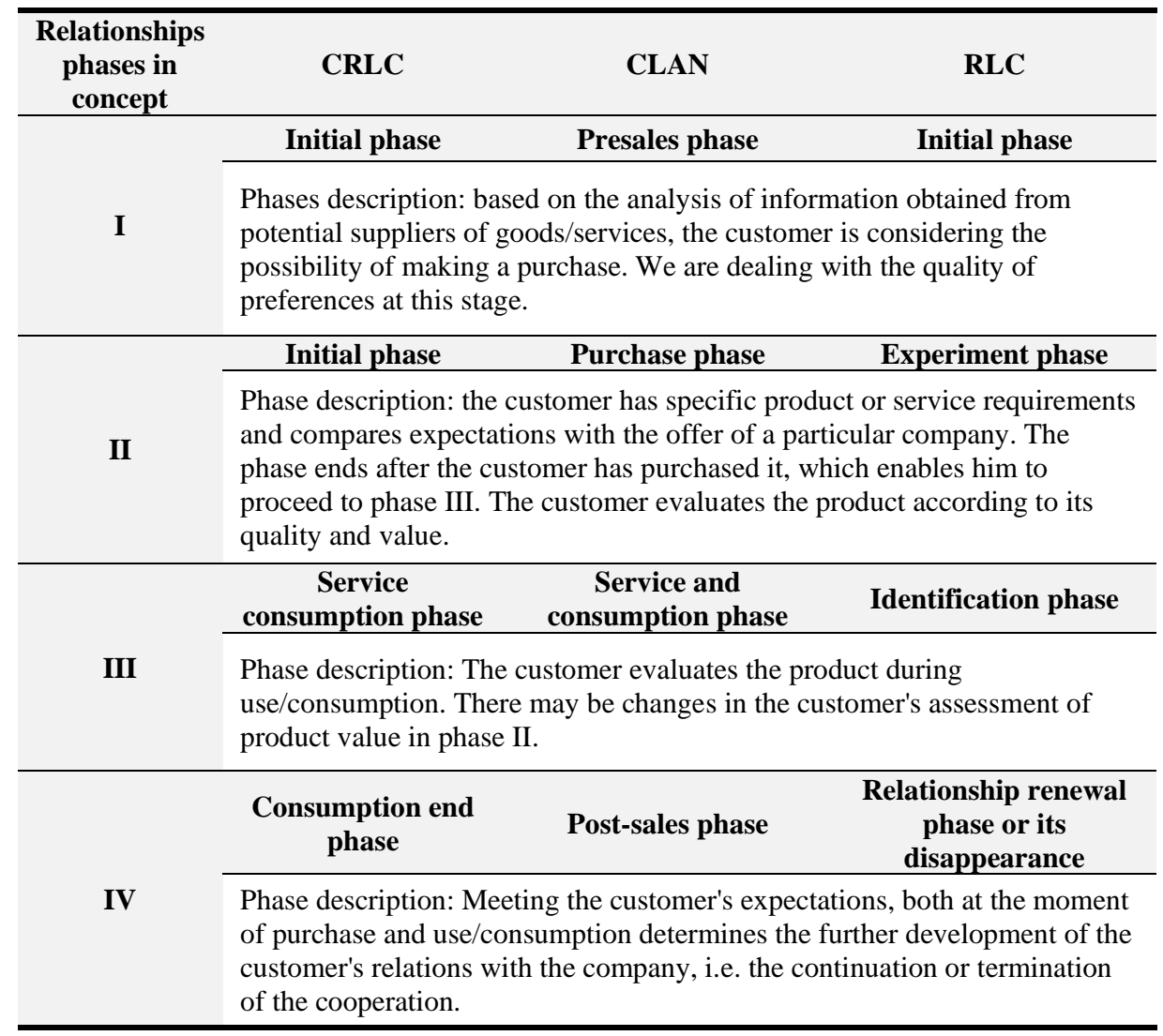

Taking into account the context of customer value and value offered by a company in the analysis of the article topic, an important aspect can be seen in the cost impact on the scope of customer service. J. Horovitz has proposed three price levels and service packages for low priced customers, performance seeking, and development customers. A general model of these relationships is shown in Fig. 1. 


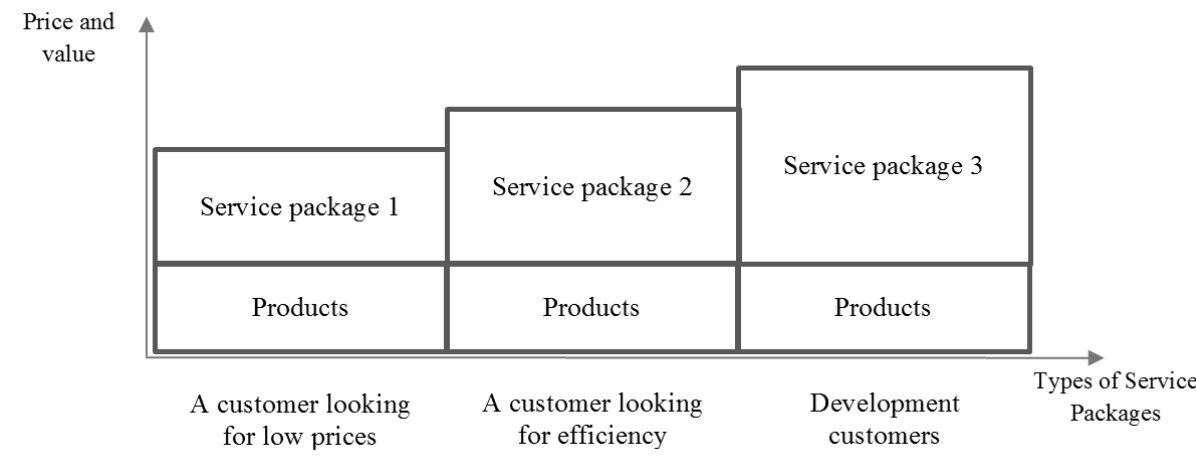

Fig. 1. Price levels of industrial service packages [9].

The assumption of the model shown in Fig. 1 is that each subsequent package includes an increased number of services while maintaining the same characteristics of the product offered. However, it is important to remember about the need to ensure and maintain customer profitability. Nowadays, the struggle for a customer should not lead to actions aimed at getting rid of unprofitable customers but rather changes in marketing strategies aimed at making their customers profitable for the company" [2]. In order to reduce the cost of the relationship, the following measures could be used [4]:

- limit customer relations,

- applying cheaper variants of relations,

- changing the cost structure of the relationship, e. g. introduction of information technology.

In the authors' opinion, the risk of running a business activity is an important aspect affecting quality management in the customer service process. "The risk of the production company originates from, among others lack of knowledge about the future state of the environment in which the enterprise will operate" [11]. "Not only the structure and the configuration of complex systems undergo constant change, but also their activity and scope of action" [7]. It is important to anticipate possible threats and to propose measures to improve and modify the existing rules of conduct (application of feedforward - controlling). Restoring service recovery "will mean the process of restoring customer satisfaction after a product or service has failed to meet expectations" [24]. Appropriate preparation of the organization enables the use of events that may become an opportunity and even an opportunity for the enterprise [18].

\section{Test methodology}

The article presents the following research problem: how to segment customers in order to ensure proper quality management of their service process. 
Research on quality management issues in the customer service process was conducted in $2013 \div 2014$ in three enterprises belonging to SMEs (small and medium-sized enterprises) [13]. The criteria for the division of small and mediumsized enterprises in accordance with Polish legislation have been adopted [26].

The selection of the sample was carried out randomly, intentionally and in a targeted manner to typical units using the snowball method. On the basis of the scope of industry demand for various construction projects presented by the manager of the General Contractor's company (construction projects implemented in the Poznan district) and a list of identified suppliers, one supplier from the leading industries, i.e. the supplier of armaments prefabrication and ferroconcrete prefabrication was randomly selected. The study assumes the names of enterprises in accordance with the specification of their activity. The first company was active in the reinforcement of reinforced concrete elements. Company 2 was involved in the production of construction elements of building structures, e. g. columns, rafters, beams and beams of bearing structures. The core business of company 3 was the manufacture of steel elements for the construction of building structures, as well as non-typical steel elements, e. g.: steel elements, steel elements, etc. small support elements, used as temporary supports on site.

The selection of companies used for the research sample took into account their size and determination of environmental conditions, which is consistent with the method indicated by $Z$. Pierścionek for research in the field of management methods [16]. All companies participating in the survey have their registered offices in Wielkopolska, Poznań district, and therefore operate under similar market and legal conditions.

The following assumptions have been made on the basis of literature analysis and presented the case study:

- Customer service consists of building and developing relationships with customers and other market players in order to establish long-term, mutually beneficial cooperation [1],

- High customer service levels can result in high costs and too low costs can lead to their loss. Each company must therefore individually determine the cost-benefit balance, if not for an individual customer, at least for the segments identified [21].

In order to identify the presented research problem, the following were applied:

- a diagnostic method, consisting of the identification of the existing state of matters, its causes, and phases. It is the basis for rational decision-making. The diagnosis is based on a causal and comparative analysis, aimed at identifying the organization's deficiencies and defects, as well as their origins. The final aspect of the method is the design and preparation for the implementation of necessary improvements [25].

- The analysis method, defined as "a method of cognition of objects, phenomena and causally-effect relationships between these elements" [20]. It usually takes place in two phases. The first phase consists of identifying the parameters of the problem, i.e. mutually dependent factors, features of the function or elements 
of the problem, and the second in searching for possible states of these parameters. It can, therefore, be said that the method of analysis consists in determining the detailed structure of the problem in question [15].

Studies were carried out in three stages:

- Stage 1: interviews on company's activities (e. g. business development stage, sales market), employees (e. g. professional development stage, motivation system), customers (e. g. characteristics of the customer portfolio, customer segmentation), customer service process (e. g. business activity, customer service). The scope of service, reasons for complaints, identification of information and its flow in the process. These interviews were supported by a partially structured survey. The questionnaire was prepared in two parts. The first part included questions addressed to the employees involved in the implementation of the customer service process (with the possible support of the Quality Management Officer) - I, and the second part was addressed to the company's top management/managers (with possible support of the Quality Management Officer) - II,

- Stage 2: analysis and evaluation of internal documentation of enterprises, including customer service contracts, procedures, and instructions for customer service.

- Stage 3: confronting the opinions of respondents (I and II) with their customers' opinions on the quality of services provided by the company and the risks identified in the course of the customer service process. In this respect, interviews were conducted with the bridge designer from the independent Design Office and with the representative of the General Contractor.

\section{Test results}

On the basis of literature analysis and research results of stages $1 \div 3$ the following were developed:

- criteria for customer segmentation,

- general characteristics of the behavior of enterprises towards target customer groups,

- levels of packages of customer service activities.

A set of information describing customer segments adequate to the industry specifics of the surveyed companies is presented in the Table below 2. Customer segments described in the Table 2 can be characterized as:

- individuals and small businesses looking for low prices,

- SMEs, which are primarily looking for effectiveness,

- big companies, with development potential. 
Table 2. Criteria for customer segmentation.

\begin{tabular}{|c|c|c|c|c|}
\hline $\begin{array}{r}\text { Criteria } \\
\text { segmenta } \\
\text { seg }\end{array}$ & $\begin{array}{l}\text { r customer } \\
\text { on/customer } \\
\text { ents. }\end{array}$ & $\begin{array}{l}\text { Individual } \\
\text { orders and } \\
\text { orders from } \\
\text { SMEs. }\end{array}$ & $\begin{array}{l}\text { Orders from } \\
\text { SMEs. }\end{array}$ & $\begin{array}{c}\text { Orders from large } \\
\text { construction companies. }\end{array}$ \\
\hline \multirow{5}{*}{$\begin{array}{l}\text { Customer } \\
\text { financial } \\
\text { structure } \\
\text { - order } \\
\text { value/perc } \\
\text { entage of } \\
\text { orders. }\end{array}$} & \multirow{2}{*}{ Company 1} & to 20 thousand & $20 \div 50$ thousand & 50 thousand and more \\
\hline & & \multicolumn{2}{|c|}{ approx. $50 \%$ of orders } & approx. $50 \%$ of orders \\
\hline & \multirow{2}{*}{ Company 2} & $\begin{array}{l}20 \div 100 \\
\text { thousand }\end{array}$ & $\begin{array}{l}100 \div 300 \\
\text { thousand }\end{array}$ & 300 thousand and more \\
\hline & & $1 \%$ of orders & $19 \%$ of orders & $\begin{array}{l}80 \% \text { of orders }(5 \div 10 \\
\text { projects per year })\end{array}$ \\
\hline & Company 3 & no data & no data & no data \\
\hline \multicolumn{2}{|l|}{ Margin } & \multicolumn{2}{|c|}{ high, even up to $100 \%$} & low margin $1 \div 2 \%$ \\
\hline
\end{tabular}

The identification of three target customer groups requires adopting the general behavioral characteristics of each segment as presented in chart 3 below.

Table 3. General characteristics of the behavior of enterprises towards their target customer groups.

\begin{tabular}{|c|c|c|c|}
\hline $\begin{array}{l}\text { Undertaken } \\
\text { actions/customer } \\
\text { segments }\end{array}$ & $\begin{array}{l}\text { Individual order } \\
\text { and order from } \\
\text { the SME. }\end{array}$ & $\begin{array}{l}\text { Orders from } \\
\text { SMEs. }\end{array}$ & $\begin{array}{l}\text { Orders from large construction } \\
\text { companies. }\end{array}$ \\
\hline $\begin{array}{l}\text { Who initiates the } \\
\text { process? }\end{array}$ & customers & $\begin{array}{l}\text { employees } \\
\text { looking for } \\
\text { investment }\end{array}$ & $\begin{array}{l}\text { large companies or employees } \\
\text { looking for investment }\end{array}$ \\
\hline $\begin{array}{l}\text { Reason for taking the } \\
\text { order. }\end{array}$ & \multicolumn{2}{|c|}{$\begin{array}{l}\text { - } \text { replenishment of orders } \\
\text { portfolio investments that } \\
\text { enable loading a monthly } \\
\text { work schedule, } \\
\text { - } \text { short-term orders }\end{array}$} & $\begin{array}{l}- \text { replenishment of orders } \\
\text { portfolio investments that will } \\
\text { allow for the completion of the } \\
\text { work schedule for the next year } \\
\text { and subsequent years, } \\
- \text { taken to implement at least } \\
\text { from six months in advance }\end{array}$ \\
\hline $\begin{array}{l}\text { The accepted method } \\
\text { of reducing the cost } \\
\text { of an order. }\end{array}$ & \multicolumn{2}{|c|}{$\begin{array}{l}\text { Basic analysis of waste quantity } \\
- \text { a improvement of the project } \\
\text { in terms of materials utilization. }\end{array}$} & $\begin{array}{l}\text { Detailed analysis of waste } \\
\text { quantities - project optimization } \\
\text { and use of materials. }\end{array}$ \\
\hline $\begin{array}{l}\text { Provisions in } \\
\text { contractual penalties } \\
\text { for failure to meet the } \\
\text { delivery deadline. }\end{array}$ & no & no & present \\
\hline $\begin{array}{l}\text { The penalty for the } \\
\text { customer for delays } \\
\text { in delivery. }\end{array}$ & no & no & present \\
\hline
\end{tabular}


Based on the information provided in the Table 3, it can be concluded that [13]:

- By providing the expected value of the relationship with the client under consideration for development clients, the company has to cover the margin of very high service costs in relation to other segments,

- The lowest customer service costs can be identified for the group of individual customers and small businesses that tend to look for low prices,

- The analysis of the costs of particular packages and their configuration would enable more accurate prediction of the profitability of offered solutions (product + service).

For the selected segments, three groups of price levels and packages of industrial services were developed in accordance with J. Horovitz's assumptions, presented in the Table 4 below.

Table 4. Levels of packages of customer service activities.

\begin{tabular}{|c|c|c|c|}
\hline $\begin{array}{l}\text { Cost of } \\
\text { customer } \\
\text { service } \\
\end{array}$ & $\begin{array}{l}\text { Individual } \\
\text { client/small } \\
\text { business } \\
\end{array}$ & SMEs & Large company \\
\hline \multirow{13}{*}{ (n) } & & & individually selected activities \\
\hline & & & service, 30 days warranty \\
\hline & & service, warranty & \multirow{2}{*}{$\begin{array}{l}\text { extended payment terms } 60 \div 90 \text { days (settlement } \\
\text { phase) }\end{array}$} \\
\hline & & \multirow{2}{*}{$\begin{array}{l}\text { payment terms of } \\
30 \text { days }\end{array}$} & \\
\hline & & & \multirow{2}{*}{$\begin{array}{l}\text { 24-hour contract manager in the office and } \\
\text { outside it }\end{array}$} \\
\hline & & \multirow{2}{*}{$\begin{array}{l}\text { care of the } \\
\text { selected staff in } \\
\text { the office } \\
\text { hours: } 8 \div 16: 00\end{array}$} & \\
\hline & \multirow{2}{*}{$\begin{array}{l}\text { service, } \\
\text { warranty }\end{array}$} & & \multirow{3}{*}{$\begin{array}{l}\text { planning and adjusting delivery dates to meet } \\
\text { customer needs }\end{array}$} \\
\hline & & \multirow{3}{*}{$\begin{array}{l}\text { agree on possible } \\
\text { delivery times } \\
\text { for the company }\end{array}$} & \\
\hline & cash payment & & \\
\hline & \multirow{2}{*}{$\begin{array}{l}\text { personal } \\
\text { collection }\end{array}$} & & \multirow{3}{*}{$\begin{array}{l}\text { advising on optimization solutions and current } \\
\text { changes }\end{array}$} \\
\hline & & \multirow{2}{*}{$\begin{array}{l}\text { consulting in } \\
\text { range of } \\
\text { optimization } \\
\text { solutions }\end{array}$} & \\
\hline & $\begin{array}{l}\text { advice on } \\
\text { mistakes made } \\
\text { in projects } \\
\end{array}$ & & \\
\hline & product & product & product \\
\hline
\end{tabular}

Taking into account the importance of customer segmentation, customer service quality and the costs of this process, it is possible to identify potential aspects of 
particular importance from the point of view of customer service quality management:

- identification of the company's customers and recognition of customer expectations and processing of complaints - stage $1 \div 3$ research,

- customer differentiation according to the revenues and profits generated by them (customer segmentation) - see the Table 2,

- adjusting the company's offer by influencing the creation of value for the customer while taking care of the increase in revenues and profits for the company - see the Table 4.

\section{Summary}

The article discusses the following research problem: how to segment customers in order to ensure proper quality management of their service process.

The theoretical part discusses the aspects related to the subject of the article and defines the most important concepts.

The empirical part presents the adopted methodology of research. The scope of research carried out in three stages was also clarified. On the basis of the identified target customer groups and the J. Horovitz's model, which depicts the relationship between the scope of customer service and the specificity of customer segments, three price levels, and service packages have been developed: for low-priced customers, customers looking for efficiency and growth customers.

The issues important for the continuation of the discussion on the subject of quality management in the customer service process should include: risk analysis in the customer service process, taking into account the customer's life cycle.

\section{References}

1. Christopher, M. et al.: Relationship marketing: Bringing quality, customer service and marketing together. International Business Review 4(4), 538-541 (1995), DOI: 10.1016/0969-5931(95)90007-1.

2. Dobiegała-Korona, B., Doligalski, T.: Zarządzanie Wartością Klienta. Pomiar i strategie. Poltex, Warszawa (2010).

3. Firlej, K., Kowalska, A., Piwowar, A.: Competitiveness and innovation of the Polish food industry. Agricultural Economics (Zemědělská ekonomika) 63 (2017), DOI: 10.17221/111/2016-AGRICECON

4. Furtak, R.: Marketing partnerski na rynku usług. Polskie Wydawnictwo Ekonomiczne, Warszawa (2003).

5. Gajdzik, B.: Troska o jakość w łańcuchu dostaw. Problemy Jakości 45(5), 19-23 (2013).

6. Grudowski, P.: Podejście procesowe w systemach zarządzania jakością w małych i średnich przedsiębiorstwach. Wydawnictwo Politechniki Gdańskiej, Gdańsk (2007).

7. Grzybowska, K., Hoffa, P.: Approving with Application of an Electronic Bulletin Board, as a Mechanism of Coordination of Actions in Complex Systems. In: Omatu, S. et al. (eds.) Distributed Computing and Artificial Intelligence, 12th 
International Conference. pp. 357-365 Springer International Publishing, Cham (2015), DOI: 10.1007/978-3-319-60285-1_17.

8. Grzybowska, K., Kovács, G.: The modelling and design process of coordination mechanisms in the supply chain. Journal of Applied Logic 24, 25-38 (2017), DOI: $10.1016 /$ j.jal.2016.11.011.

9. Horovitz, J.: Strategia obsługi klienta. Polskie Wydawnictwo Ekonomiczne, Warszawa (2006).

10. Jasiulewicz-Kaczmarek, M., Saniuk, A.: Human Factor in Sustainable Manufacturing. In: Antona, M., Stephanidis, C. (eds.) Universal Access in Human-Computer Interaction. Access to the Human Environment and Culture. pp. 444-455 Springer International Publishing, Cham (2015), DOI 10.1007/9783-319-20687-5_43.

11. Kaczmarek, T. T.: Zarządzanie ryzykiem. Ujęcie interdyscyplinarne. Difin, Warszawa (2010).

9. Kowalska, A., Olszańska A., Urban S.: Marketing produktów spożywczych i gastronomii. Wydawnictwo Uniwersytet Ekonomiczny we Wrocławiu, Wrocław (2016).

10. Marczewska-Kuźma, R.: Metodyka zarządzania jakością procesu obsługi klienta. Praca doktorska. Politechnika Poznańska, Wydział Inżynierii Zarządzania (2015).

14. Marczewska-Kuźma, R., Kawecka-Endler, A.: Analiza wybranych czynników ryzyka w zarządzaniu procesem obsługi klienta. In: Innowacje w zarządzaniu i inżynierii jakości, pp. 409-419. Oficyna Wydawnicza Polskiego Towarzystwa Zarządzania Produkcją, Opole (2014).

12. Martyniak, Z.: Wstęp do inwentyki. 2nd edn. Wydawnictwo Akademii Ekonomicznej w Krakowie, Kraków (1997).

13. Pierścionek, Z.: Strategie konkurencji i rozwoju przedsiębiorstwa. Wydawnictwo Naukowe PWN, Warszawa (2007).

14. PN-IS0 9000:2015: Systemy zarządzania jakością - Podstawy i terminologia.

15. PN-IS0 9001:2015: Systemy zarządzania jakością - Wymagania.

16. Rogoziński, K.: Nowy marketing usług. Wydawnictwo Akademii Ekonomicznej w Poznaniu, Poznań (2000).

17. Sierpińska, M., Jachna, T.: Ocena przedsiębiorstwa według standardów światowych. Wydawnictwo Naukowe PWN, Warszawa (2004).

21. Skoczylas, K.: Koszty i controlling logistyki w przedsiębiorstwie. Politechnika Rzeszowska, Rzeszów (2010).

19. Skowron, S., Skowron, Ł.: Lojalnosc klienta a rozwój organizacji. Difin, Warszawa (2012).

20. Tzokas, N., Saren, M.: Competitive advantage, knowledge and relationship marketing: where, what and how? Journal of Business \& Industrial Marketing 19(2), 124-135 (2004), DOI: 10.1108/08858620410524007

21. Wood, D., Jr. Murphy, P.R.: Contemporary Logistics. Pearson Education, London (2014).

22. Ziemski, S.: Problemy dobrej diagnozy. Wiedza Powszechna, Warszawa (1973).

23. Ustawa z dnia 2 lipca 2004 r. o swobodzie działalności gospodarczej, Dz. U. z 2004 r. Nr 17, poz. 1807. 